\title{
Clinical Features and Disease Severity in Patients With Mosaic Neurofibromatosis Type 1: A Single- Center Study and Literature Review
}

Maj Raundahl ( $\sim$ maj.raundahl@hotmail.com )

Centre for Rare Diseases, Department of Paediatrics and Adolescent Medicine https://orcid.org/00000001-8006-4749

\section{Pernille Axel Gregersen}

Department of Clinical Genetics, Aarhus University Hospital

\section{Mette Møller Handrup}

Centre for Rare Diseases, Department of paediatrics and Adolescent Medicin, Aarhus University Hospital

\section{Cecilie Ejerskov}

Centre for Rare Diseases, Department of paediatrics and adolescent Medicine, Aarhus University Hospital

\section{Research}

Keywords: Neurofibromatosis type 1, neurofibroma, plexiform neurofibroma, mosaicism, mosaic, NF1 gene, NF1 guideline.

Posted Date: October 28th, 2020

DOl: https://doi.org/10.21203/rs.3.rs-96774/v1

License: (c) (i) This work is licensed under a Creative Commons Attribution 4.0 International License.

Read Full License

Version of Record: A version of this preprint was published at Orphanet Journal of Rare Diseases on April 14th, 2021. See the published version at https://doi.org/10.1186/s13023-021-01796-3. 


\section{Abstract}

Background The mosaic form of neurofibromatosis type 1 (NF1) is called mosaic NF1 (MNF1). No specific MNF1 follow-up guidelines exist. It is debatable if patients with MNF1 should be clinically examined and undergo follow-up in accordance with the standard NF1 guidelines, as MNF1 patients more often may develop more benign phenotypes and thereby less disease-associated complications including cognitive impairment. We discussed the need for a specific MNF1 follow-up guideline with focus on frequency of plexiform neurofibromas and NF1-associated complications.

Method A systematic retrospective data collection in a MNF1 cohort from one of two Danish national centers of NF1 Expertise was completed. Data collected included demographics, clinical features including NF1 diagnostic criteria and NF1-associated complications. Recent literature in the field was reviewed.

Results We identified 17 patients with MNF1 with a median age of 37 years $[4 ; 66]$. Eleven $(65 \%)$ were females. Five patients (30\%) had a plexiform neurofibroma. The median age at detection of plexiform neurofibroma was 30 years $[14 ; 60]$. Nine $(53 \%)$ had at least one NF1-related complication; scoliosis, hypertension, ADHD, learning disability, language delay, autism and delay in gross and fine motor function development. We reviewed nine articles. In total, 126 cases were described within three caseseries. Nineteen (15\%) had a plexiform neurofibroma and in total, 23 NF1-associated complications were reported including language delay, learning disability and skeletal abnormalities. Furthermore, from the literature it was evident that the diagnosing of MNF1 varies among physicians and across countries.

Conclusion Patients with MNF1 present with plexiform neurofibromas and other NF1-related complications with a frequency requiring that follow-up of MNF1 patients should be in accordance with the standard NF1 guideline in both childhood and adulthood. Physicians should be aware of cognitive impairment as a complication to MNF1. To develop a specific MNF1 follow-up guideline, there is a need for an international consensus on the diagnostic criteria for MNF1 and a follow-up study conducted in a larger MNF1 cohort.

\section{Introduction}

Neurofibromatosis type 1 (NF1) is a complex neurocutaneous disorder caused by loss of function variants and microdeletions in the NF1 gene coding for the protein neurofibromin $(1,2)$. With an incidence between 1: 2000 and 1: $3000, N F 1$ is one of the more common rare diseases $(3,4)$. Fifty percent of NF1 cases are hereditary and the remaining are caused by de novo NF1 variants (5). NF1 is characterized by the clinical features café-au-lait (CAL) spots, axillary and inguinal freckling, neurofibromas and Lisch nodules; these features are present in the vast majority of patients. Other clinical features in a significant proportion of patients include plexiform neurofibromas and different NF1-associated complications including learning disabilities, skeletal dysplasia, and an increased risk of specific malignancies (6). 
NF1 exists as a mosaic form called mosaic NF1 (MNF1) caused by postzygotic pathogenic variants in NF1. NF1 spans approximately $350 \mathrm{~Kb}$ of genomic DNA and has one of the highest mutation rates, resulting in a relatively high frequency of mosaicism $(7,8)$. Disease-associated manifestations of MNF1 are limited to the affected area of the body, from a small part to half the body. Manifestations are usually unilateral but may appear bilaterally, either in a symmetric or asymmetrical form (8).

It is debatable if patients with MNF1 should be clinically examined and undergo follow-up in accordance with the standard NF1 guidelines, as patients with MNF1 may more often develop more benign phenotypes and have a much lower risk of developing plexiform neurofibromas and NF1-associated complications such as cognitive impairment and malignancy $(5,8-10)$. A systematic review of 157 cases of MNF1 published between 1977 and 2012 found that 11.5\% had plexiform neurofibromas, $29 \%$ had NF1-associated complications and $13 \%$ had a risk of malignancy, especially if they had neurofibromas (11). Between $30 \%$ and $50 \%$ of patients with NF1 develop plexiform neurofibromas $(12,13)$. Plexiform neurofibromas are congenital benign peripheral nerve sheath tumors localized in the head, neck, limbs, truncus, thorax as well as the abdominal and pelvic cavity. It is estimated that large lesions account for $5 \%$ of all plexiform neurofibromas (13). Currently, the only standard treatment for plexiform neurofibromas is surgical resection. However, given the infiltrative nature and size of plexiform neurofibromas, complete surgical removal is usually not possible (14). Last year, selumetinib, a small molecule MEK inhibitor which has been proven to decrease tumor volume of plexiform neurofibromas in children with NF1 was approved by US Food and Drug Administration to treat congenital and inoperable plexiform neurofibromas in children with NF1 (15). Plexiform neurofibromas can transform into malignant peripheral nerve sheet tumors (MPNST), which is one of the most common NF1-related malignancies (16). MPNST is an aggressive sarcoma, difficult to detect and with a poor prognosis. It is rare in the general population (incidence $0.001 \%$ ), but the incidence in patients with NF1 has been found to be $2-5 \%$ with a cumulative lifetime risk of $8-13 \%(17)$.

While there are internationally accepted guidelines for the diagnosis and management of NF1, there are no specific guidelines on MNF1 $(8,12)$. Due to the new treatment of plexiform neurofibromas, selumetinib, it is of interest to report plexiform neurofibromas in patients with MNF1. We present data from a cohort of patients with MNF1 with focus on the proportion of neurofibromas, plexiform neurofibromas, MPNST, and other NF1-associated complications. We also present a review of literature on MNF1 published between 2013 and 2020 with focus on plexiform neurofibromas and NF1-associated complications. Furthermore, this study will discuss the need for a specific MNF1 follow-up guideline.

\section{Methods}

\section{The MNF1 cohort}

Patients with MNF1 were included from the outpatient clinic at the Centre for Rare Diseases (CRD), Department of Paediatrics and Adolescent Medicine, Aarhus University Hospital, one of two Danish national specialist centers for NF1 covering the western part of Denmark. The center monitors patients 
with NF1 from infancy until old age, regardless of severity of NF1. There is free and equal access to healthcare for all residents in the Danish tax-based healthcare system.

\section{Protocol}

We conducted a cross-sectional study. A systematic data collection from the MNF1 cohort was completed. Data included demographic characteristics (age, sex, date of diagnosis), clinical features of NF1 according to the diagnostic criteria of NF1 (18); pigmentary changes, neurofibromas, plexiform neurofibromas, Lisch nodules; optic pathway glioma, skeletal dysplasia and family history of NF1 and NF1 analysis (if performed). We collected any additional information on associated NF1 complications such as skeletal abnormalities, development difficulties and malignancies.

Based on the clinical features, each patient was categorized according to the four MNF1 categories suggested by Ruggieri and Huson: 1) pigmentary changes only, 2) pigmentary changes and neurofibromas, 3) neurofibromas only, and 4) plexiform neurofibromas only (8).

Primary outcomes were the development of plexiform neurofibromas including the proportion of patients with MNF1 with plexiform neurofibroma and age at presentation. Secondary outcomes were the proportion of all clinical characteristics including NF1-associated complications and the results of NF1 analysis (if performed).

\section{Data analysis}

Data were collected and managed using the Research Electronic Data Capture (REDCap) tool hosted by Department of Clinical Medicine, Aarhus University. REDCap is a web-based platform designed to safe handling of data capture for research and automated export functions for data downloads $(19,20)$. The clinical features including NF1 analysis were studied retrospectively. Descriptive statistics were calculated using counts and proportions for categorical variables and medians and ranges for continuous variables.

\section{Literature on MNF1}

A literature search was performed in PubMed in September 2020 using the following MESH terms: ((("Neurofibromatoses"[Mesh]) OR "Neurofibromatosis 1"[Mesh])) AND “Mosaicism"[Mesh]). We limited the search to articles written in English and published between 2013 and 2020. The inclusion criteria were 1) case reports describing patients who had localized manifestations of NF1 according to MNF1 and 2) case series including adequate clinical information on each patient with MNF1. Adequate information was demographics; sex, age at presentation; and disease manifestations, type and location of manifestations, other conditions or complications associated with NF1, or/and results of NF1 analysis (if performed).

\section{Results}




\section{The MNF1 cohort}

\section{Clinical features}

Seventeen patients, 11 females (65\%), with MNF1 were identified. At inclusion, the median age was 37 years [4; 83]. Table 1 presents the MNF1 cohort according to the four MNF1 categories. Eight patients had only pigmentary changes, two patients had both pigmentary changes and neurofibromas, five patients had only neurofibromas and two patients had only plexiform neurofibromas. Patients with only pigmentary changes were younger at time of the MNF1 diagnosis with a median age of nine years $[1 ; 16]$ compared to patients with only neurofibromas with a median age of 40 years [29; 77]. Patients with only plexiform neurofibromas had a median age of 28 years [25;31] at the date of MNF1 diagnosis; the plexiform neurofibromas were, however, generally identified before the MNF1 diagnosis when patients had a median age of 17 years $[14 ; 20]$.

NF1-associated complications were hypertension, scoliosis, learning disability, delay of language and cognition, infantile autism, attention deficit hyperactivity disorder (ADHD) and delay in gross and fine motor function development. In total, nine (53\%) patients had one or more complications associated to NF1. Table 1 presents the complications at individual patient level. No patients were diagnosed with optic pathway glioma, bone dysplasia or malignant disease including MPNST at the time of data collection.

Table 1. The MNF1 cohort from Centre for Rare Diseases ( $n=17)$. 


\begin{tabular}{|c|c|c|c|c|c|}
\hline & Total & $\begin{array}{l}\text { Pigmentary } \\
\text { changes } \\
\text { only }\end{array}$ & $\begin{array}{l}\text { Pigmentary } \\
\text { changes and } \\
\text { neurofibromas }\end{array}$ & $\begin{array}{l}\text { Neurofibromas } \\
\text { only }\end{array}$ & $\begin{array}{l}\text { Plexiform } \\
\text { neurofibromas } \\
\text { only }\end{array}$ \\
\hline Patients, n & 17 & 8 & 2 & 5 & 2 \\
\hline $\begin{array}{l}\text { Females, } n \\
(\%)\end{array}$ & $11(64.7 \%)$ & $6(75 \%)$ & $1(50 \%)$ & $3(60 \%)$ & $1(50 \%)$ \\
\hline $\begin{array}{l}\text { Median } \\
\text { age, y } \\
\text { [range] }\end{array}$ & $37[4 ; 83]$ & $18[4 ; 37]$ & $59[51 ; 66]$ & $56[37 ; 83]$ & $37[33 ; 40]$ \\
\hline $\begin{array}{l}\text { Median } \\
\text { age at } \\
\text { MNF1 } \\
\text { diagnosis, } \\
\text { y [range] }\end{array}$ & $25[1 ; 77]$ & $9[1 ; 16]$ & $54[46 ; 61]$ & $40[29 ; 77]$ & 28 [25;31] \\
\hline $\begin{array}{l}\text { CAL spots, } \mathrm{i} \\
\text { patients (\%) }\end{array}$ & n number of & $8(100 \%)$ & $2(100 \%)$ & 0 & 0 \\
\hline & $\begin{array}{l}\text { Head and neck, n } \\
(\%)\end{array}$ & 1 (12.5\%) & - & - & - \\
\hline & Trunk, n (\%) & $7(87.5 \%)$ & $2(100 \%)$ & - & - \\
\hline & $\begin{array}{l}\text { Upper extremities, } \\
\text { n (\%) }\end{array}$ & $2(25 \%)$ & - & - & - \\
\hline & $\begin{array}{l}\text { Lower extremities, } \\
\mathrm{n}(\%)\end{array}$ & $5(62.5 \%)$ & $1(50 \%)$ & - & - \\
\hline & Pelvic area, n (\%) & 3 (37.5\%) & - & - & - \\
\hline & $\begin{array}{l}\text { Size of largest } \\
\text { CAL spot (mm), } \\
\text { median [range] }\end{array}$ & $50[13 ; 150]$ & 15 & - & - \\
\hline $\begin{array}{l}\text { Freckling, in } \\
(\%)\end{array}$ & number of patients & 5 (62.5\%) & 0 & 0 & 0 \\
\hline & $\begin{array}{l}\text { Axillary unilateral, } \\
\text { n (\%) }\end{array}$ & $4(50 \%)$ & - & - & - \\
\hline & $\begin{array}{l}\text { Inguinal unilateral, } \\
\mathrm{n}(\%)\end{array}$ & $1(12.5 \%)$ & - & - & - \\
\hline $\begin{array}{l}\text { Neurofibrom } \\
\text { patients (\%) }\end{array}$ & as, in number of & - & $1(50 \%)$ & $5(100 \%)$ & 0 \\
\hline & $\begin{array}{l}\text { Head and neck, n } \\
(\%)\end{array}$ & - & - & $1(20 \%)$ & - \\
\hline & Trunk, n (\%) & - & $1(50 \%)$ & $4(80 \%)$ & - \\
\hline & $\begin{array}{l}\text { Lower extremities, } \\
\text { n (\%) }\end{array}$ & - & - & $2(40 \%)$ & - \\
\hline
\end{tabular}




\begin{tabular}{|c|c|c|c|c|}
\hline Pelvic area, n (\%) & - & - & $2(40 \%)$ & - \\
\hline $\begin{array}{l}\text { Size of largest } \\
\text { neurofibroma } \\
\text { (mm), median } \\
\text { [range] }\end{array}$ & - & 4 & $40[4 ; 50]$ & - \\
\hline $\begin{array}{l}\text { Plexiform neurofibromas, } \\
\text { in number of patients (\%) }\end{array}$ & 0 & $1(50 \%)$ & $2(40 \%)$ & $2(100 \%)$ \\
\hline $\begin{array}{l}\text { Head and neck, n } \\
(\%)\end{array}$ & - & - & - & $2(100 \%)$ \\
\hline $\begin{array}{l}\text { Lower extremities, } \\
\mathrm{n}(\%)\end{array}$ & - & $1(50 \%)$ & $1(20 \%)$ & - \\
\hline Pelvic area, n (\%) & - & - & $2(40 \%)$ & - \\
\hline $\begin{array}{l}\text { Median age by } \\
\text { detecting of } \\
\text { plexiform } \\
\text { neurofibroma, y } \\
\text { [range] }\end{array}$ & - & 60 & $35[30 ; 40]$ & $17[14 ; 20]$ \\
\hline $\begin{array}{l}\text { Lisch nodules, in number of } \\
\text { patients (\%) }\end{array}$ & $1(12.5 \%)$ & $1(50 \%)$ & 0 & 0 \\
\hline Unilateral, n (\%) & 0 & 0 & - & - \\
\hline Bilateral, n (\%) & $1(100 \%)$ & $1(50 \%)$ & - & - \\
\hline $\begin{array}{l}\text { NF1 associated complications, } \\
\text { in number of patients }(\%)\end{array}$ & $4(50 \%) \star$ & 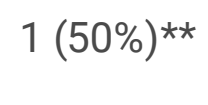 & 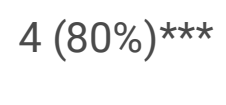 & 0 \\
\hline
\end{tabular}

* Scoliosis $(n=2)$, learning disability $(n=1)$, reading difficulties $(n=1)$, infantile autism $(n=1), \operatorname{ADHD}(n=1)$, delayed for age $(n=1)$, gross and fine motor function delays $(n=1)$, language delay $(n=1)$.

** Scoliosis and language delays $(n=1)$.

$\star \star \star ~ H y p e r t e n s i o n ~(n=4)$, learning disability $(n=1)$.

\section{NF1 variants}

Six patients had had a NF1 analysis performed. A variant was detected in two patients (Table 2). In patient no. 12, a disease-associated variant (c.3721C>T (p.Arg1241)) was detected in DNA from a neurofibroma, whereas the result of the analysis on DNA from blood was normal. This patient had two CAL spots, more than six neurofibromas and bilateral Lisch nodules. In patient no. 17, a pathogenic variant (c.5814_5815delTT) was detected in a mosaic form both in the DNA from a neurofibroma and in the DNA from blood. The only clinical feature of NF1 was more than six neurofibromas. Gonadal mosaicism was confirmed as the patient had a child with the same NF1 variant in the germline (i.e. nonmosaic variant in DNA from blood) and generalized NF1.

Table 2. Results of the NF1 analyses in the MNF1 cohort from Centre for Rare Diseases. 


\begin{tabular}{|llll|}
\hline Patient & Sample & $\begin{array}{l}\text { Analysis } \\
\text { method }\end{array}$ & Result of NF1 analysis \\
\hline 10 & Blood (B-lymphocytes) & MLPA analysis & Negative \\
\hline 12 & Neurofibroma & NGS and MLPA & $\begin{array}{l}\text { Disease-associated variant } \\
\text { (c.3721C>T(p.Arg1241)) }\end{array}$ \\
\cline { 2 - 4 } & Blood & $-*$ & Negative \\
\hline 14 & $\begin{array}{l}\text { Blood and plexiform } \\
\text { neurofibroma }\end{array}$ & NGS and MLPA & Negative \\
\hline 15 & Blood and CAL spot & $-*$ & Negative \\
\hline 17 & Blood & NGS and MLPA & Negative \\
\hline
\end{tabular}

MLPA = Multiplex Ligand-dependent Probe Amplification, NGS = Next Generation Sequencing.

* Information on the analysis method was not available.

\section{Review of the literature}

We identified 26 articles in our literature search in the PubMed database (Figure 1). Nine articles were included in the study consisting of three case series and six case reports.

\section{Clinical features}

The patients with MNF1 included in the case series were recruited from hospitals or clinical centers and the patient cohorts were described in general $(10,21,22)$. In total, 126 cases were found in the three case series. The cases are presented in Table 3. Nineteen out of $126(15 \%)$ cases had plexiform neurofibromas and in total, 23 NF1-associated complications were reported. The two most reported complications were skeletal abnormalities and learning disabilities followed by ADHD, language delay and intracranial vasculopathy.

Table 3.126 cases from three case series presented in total and individual articles. 


\begin{tabular}{|c|c|c|c|c|c|}
\hline & $\begin{array}{l}\text { Number } \\
\text { of } \\
\text { patients }\end{array}$ & $\begin{array}{l}\text { Mean } \\
\text { age, } \\
\text { years }\end{array}$ & $\begin{array}{l}\text { Females, } \\
\mathrm{n}(\%)\end{array}$ & Four categories & $\begin{array}{l}\text { NF1-associated } \\
\text { complications }\end{array}$ \\
\hline $\begin{array}{l}\text { Total } \\
(10,21 \text {, } \\
22)\end{array}$ & $n=126$ & $\begin{array}{l}\text { Mean } \\
\text { age }= \\
16.44 \\
\pm 0.6 \\
\text { years }\end{array}$ & $\begin{array}{l}76 \\
(60 \%)\end{array}$ & $\begin{array}{l}\text { Pigmentary changes only ( } \mathrm{n} \\
=79) \text {, neurofibromas only }(\mathrm{n} \\
=14) \text {, pigmentary changes } \\
\text { and neurofibromas }(\mathrm{n}=15) \text {, } \\
\text { plexiform neurofibromas } \\
\text { only }(n=18) \text {. }\end{array}$ & $\begin{array}{l}\text { language delay }(n=1) \text {, } \\
\text { learning disability }(n= \\
7), A D H D(n=3), \\
\text { skeletal abnormalities } \\
\text { (11) and intracranial } \\
\text { vasculopathy }(n=1) .\end{array}$ \\
\hline $\begin{array}{l}\text { Lara- } \\
\text { Corrales, } \\
\text { I., et } \\
\text { al(21) }\end{array}$ & $\mathrm{n}=60$ & $\begin{array}{l}\text { Mean } \\
\text { age }= \\
10.6 \\
\pm 4.6 \\
\text { years }\end{array}$ & $\begin{array}{l}32 \\
(53 \%)\end{array}$ & $\begin{array}{l}\text { Pigmentary changes only ( }(n \\
=39) \text {, neurofibromas only }(n \\
=9) \text {, pigmentary changes } \\
\text { and neurofibromas }(n=2) \text {, } \\
\text { plexiform neurofibromas } \\
\text { only }(n=10) \text {. }\end{array}$ & $\begin{array}{l}\text { Learning disability }(n= \\
\text { 7), bony changes }(n= \\
6) \text {, seizures }(n=1)\end{array}$ \\
\hline $\begin{array}{l}\text { Tanito, K., } \\
\text { et al(10) }\end{array}$ & $n=58$ & $\begin{array}{l}\text { Mean } \\
\text { age = } \\
23.4 \\
{[1 ; 69]} \\
\text { years }\end{array}$ & $\begin{array}{l}42 \\
(72 \%)\end{array}$ & $\begin{array}{l}\text { Pigmentary changes only ( } \mathrm{n} \\
=32) \text {, neurofibromas only }(\mathrm{n} \\
=5) \text {, pigmentary changes } \\
\text { and neurofibromas }(n=13) \text {, } \\
\text { plexiform neurofibromas } \\
\text { only }(n=8) \text {. }\end{array}$ & $\begin{array}{l}\text { Bone deformity }(n=3) \text {, } \\
\text { language delay }(n=1)\end{array}$ \\
\hline $\begin{array}{l}\text { Marwaha, } \\
\text { A., } \\
\text { et la(22) }\end{array}$ & $\mathrm{n}=8$ & $\begin{array}{l}\text { Mean } \\
\text { age = } \\
9.8 \\
{[1 ; 16]} \\
\text { years }\end{array}$ & $\begin{array}{l}2 \\
(25 \%)\end{array}$ & $\begin{array}{l}\text { Pigmentary changes only ( } \mathrm{n} \\
=7) \text {, neurofibromas only }(\mathrm{n} \\
=0) \text {, pigmentary changes } \\
\text { and neurofibromas }(n=1) \text {, } \\
\text { plexiform neurofibromas } \\
\text { only }(n=0) \text {. }\end{array}$ & $\begin{array}{l}\text { sphenoid wing } \\
\text { dysplasia }(n=1), \\
\text { intracranial } \\
\text { vasculopathy }(n=1) \text {, } \\
\text { tibial rotation }(n=1) \text {, } \\
\text { ADHD }(n=3) .\end{array}$ \\
\hline
\end{tabular}

In total, seven cases with MNF1 were presented in the six case reports (Table 4). Patients presented in the following four groups; no patients with only pigmentary changes, three patients (43\%) had neurofibromas only, three patients (43\%) had pigmentary changes and neurofibromas, and one patient (14\%) had plexiform neurofibromas only. No patients had NF1-associated complications, but one case had developed three malignancies not known to be directly related to NF1; renal cell carcinoma, mixed thyroid carcinoma and lentigo maligna (23). Another case had a daughter with generalized NF1 and two unaffected children consistent with gonadal mosaicism (24).

Table 4. Seven cases from six case reports. 


\begin{tabular}{|c|c|c|c|c|c|}
\hline Characteristics & $\begin{array}{l}\text { All } \\
\text { patients } \\
(n=7)\end{array}$ & $\begin{array}{l}\text { Pigmentary } \\
\text { changes } \\
\text { only } \\
(n=0)\end{array}$ & $\begin{array}{l}\text { Neurofibromas } \\
\text { only } \\
(n=3)\end{array}$ & $\begin{array}{l}\text { Pigmentary } \\
\text { changes and } \\
\text { neurofibromas } \\
(n=3)\end{array}$ & $\begin{array}{l}\text { Plexiform } \\
\text { neurofibromas } \\
\text { only } \\
(n=1)\end{array}$ \\
\hline $\begin{array}{l}\text { Median age, } \\
\text { years (range) }\end{array}$ & $\begin{array}{l}55 \\
{[35 ; 72]}\end{array}$ & - & $61[40 ; 72]$ & $46[35 ; 66]$ & 55 \\
\hline Female, n (\%) & $5(71 \%)$ & - & $2(67 \%)$ & $2(67 \%)$ & $1(100 \%)$ \\
\hline $\begin{array}{l}\text { CAL spots, n } \\
\text { (\%) }\end{array}$ & $2(29 \%)$ & - & - & $2(67 \%)$ & - \\
\hline Freckling, n (\%) & $2(29 \%)$ & - & - & $2(67 \%)$ & - \\
\hline $\begin{array}{l}\text { Neurofibromas, } \\
\mathrm{n}(\%)\end{array}$ & $6(86 \%)$ & - & $3(100 \%)$ & $3(100 \%)$ & - \\
\hline $\begin{array}{l}\text { Plexiform } \\
\text { neurofibromas, } \\
\text { n (\%) }\end{array}$ & $1(14 \%)$ & - & - & - & $1(100 \%)$ \\
\hline $\begin{array}{l}\text { NF1 associated } \\
\text { complications, } \\
\text { n (\%) }\end{array}$ & 0 & - & 0 & 0 & 0 \\
\hline
\end{tabular}

\section{NF1 variants}

In the case series, 22 patients had undergone a NF1 analysis performed on DNA from blood, CAL spots and plexiform neurofibromas $(21,22)$. In 11 cases a pathogenic NF1 variant was detected; an intragenic variant in nine cases and a microdeletion in two cases $(21,22)$. Within the case reports, one patient had undergone NF1 analysis and an atypical large NF1 deletion was found in DNA from three plexiform neurofibromas (25).

\section{Discussion}

In the absence of international guidelines on the follow-up on MNF1 and sparse publications on larger MNF1 cohorts, this study sought to investigate the severity of MNF1 with focus on plexiform neurofibromas in a cohort of children and adults and to perform an update of a literature review. This study is the first to present a Danish cohort of patients with MNF1 in relation to the current literature on MNF1. We found that the proportion of patients with MNF1 and plexiform neurofibromas within our cohort is higher $(29 \%)$ than described in the literature reviewed in this article $(15 \%)$ and that the diagnosis of a plexiform neurofibroma is often made before the actual MNF1 diagnosis. We also found that the phenotype severity of MNF1 in some cases is similar to the phenotype seen in generalized NF1 with many NF1-associated complications. 
We found a higher frequency of plexiform neurofibromas in our cohort $(29 \%)$ than previously reported in MNF1 literature; $6.5 \%$ in children and adults and $4 \%$ in children, and $11.5 \%$ in a systematic review of 157 children and adults $(8,11,26)$. Especially the larger plexiform neurofibromas can cause moderate to severe morbidities such as pain and/or disfigurement. Interestingly, we found the median age at the diagnosis of plexiform neurofibromas was lower than the age at the actual MNF1 diagnosis, even though plexiform neurofibromas are believed to be congenital and most often detected in childhood (10). This underlines that it can be challenging to establish the MNF1 diagnosis; moreover, the risk of developing plexiform neurofibroma after reaching adulthood cannot be neglected. It is important that physicians are aware that plexiform neurofibroma may be a sole manifestation of MNF1 and not just an idiopathic plexiform neurofibroma. Interestingly, the plexiform neurofibroma in patients with only plexiform neurofibromas was located at the head and neck of patients in our cohort. Ruggieri and Huson also found that plexiform neurofibromas were most frequently located at the head and neck (88\%) in patients with only plexiform neurofibromas (8). Lara-Corrales et al found that $73 \%$ of all plexiform neurofibromas were located at the head and neck (21). In our cohort, one patient had two plexiform neurofibromas. LaraCorrales et al found that $17 \%$ of patients who previously had plexiform neurofibromas developed new plexiform neurofibromas after a mean follow-up of $3.7 \pm 3.3$ years (21). A long-term follow-up including both children and adults with MNF1 could be beneficial to increase the clinical understanding of the development of plexiform neurofibromas. So far, only children with generalized NF1 and congenital plexiform neurofibromas qualify for treatment with selumetinib. Even if a diagnosis of MNF1 could qualify for treatment, patients with MNF1 are often diagnosed with both MNF1 and plexiform neurofibromas after reaching adulthood. In the light of the rather high number of plexiform neurofibromas in the MNF1 population, it could be advocated that patients with MNF1 have the same need of assessment for treatment with selumetinib.

Within our cohort, nine out of 17 patients (53\%) had NF1-associated complications. Cognitive impairment has previously been shown to be less frequent in patients with $\operatorname{MNF1}(8,10,26)$, but within both our cohort and the literature review we found cognitive impairment to be just as frequent as somatic complications. Any degree of cognitive impairment can be challenging to an individual, and the challenges found in this study are all biopsychosocial factors influencing quality of life. Furthermore, several studies have reported reduced quality of life in children, adolescents and adults in the NF1 population (6).

Assessing the age and phenotype of the MNF1 diagnosis, our data show that the median age at diagnosis of patients with pigmentary changes only $(n=8)$ was nine years, whereas the median age at diagnosis of patients with plexiform neurofibromas $(n=2)$ and neurofibromas only $(n=5)$ was 28 years and 40 years, respectively. According to the literature on MNF1, pigmentary changes develop in early childhood, followed by the appearance of plexiform neurofibromas in later childhood; cutaneous neurofibromas develop in adulthood(8). Since the patients in our cohort with pigmentary changes only had a median age of 18 years at inclusion, they have a risk of developing neurofibromas later in life. The presence of a mild phenotype with only few neurofibromas may not lead to seeking medical attention; this may suggest that neurofibromas are underreported in the cohorts and that MNF1 is underdiagnosed 
in the general population. In support of this, Listernick et al proposed the misdiagnosis of MNF1 as generalized NF1 in cases of significant neurofibromas(26).

Only six patients in our MNF1 cohort had had a NF1 analysis performed and a variant was only detected in two patients; no patients presented with NF1 microdeletions. In our review of the literature, 11 variants in 22 cases were detected of which two were microdeletions. Kehrer-Sawatzki et al did not find any patients with MNF1 with NF1 microdeletions to have more severe phenotypes (27). Any other genotypephenotype correlation in MNF1 has not been shown $(22,28)$. Individuals with MNF1 are at risk of gonadal mosaicism, which gives a risk of offspring with generalized NF1 and any NF1-associated complication. Within our cohort, one patient had a child with generalized NF1 $(0.6 \%)$ and in the previously published literature, frequencies were $2.5 \%$ and $6.4 \%(8,11)$. A sperm donor with no diagnosis of NF1 or MNF1 fathered nine children out of 23 (39\%) with NF1 and had an estimated $20 \%$ gonadal mosaicism for NF1 (29). This shows that an estimate of gonadal mosaicism in semen is not equal to the true proportional risk of offspring with NF1.

This study has some limitations. Our cohort consisted of a small group of patients, which makes it difficult to draw conclusions about the general MNF1 patient group. In addition, statistical calculations were not possible because of heterogenic data between our cohort and the reviewed literature and within the literature itself. NF1 analyses were only performed in six patients in our cohort; hence, it was not possible to categorize the cohort according to the genotype.

The diagnostic process of MNF1 was a challenge as this process may vary among physicians and across countries indicating the need for international clinical diagnostic criteria for MNF1. Listernick et al suggested the following criteria: A subject is defined as having MNF1 if he or she has (1) one or more $\mathrm{NIH}$ diagnostic criteria limited to one area of the body, (2) NF1 manifestations do not cross the midline, and (3) minimum age of six year (26). However, these criteria do not apply well to the MNF1 cohort as several patients had manifestations on several areas of the body sometimes crossing the midline. Lara-Corrales et al suggested that the ideal way to confirm the diagnosis of MNF1 is a positive NF1 analysis on DNA from affected tissue together with a negative NF1 analysis on DNA from blood (21). However, one of the patients from our MNF1 cohort had a positive NF1 analysis on DNA from both affected tissue and blood, though in a mosaic state and two patients had a negative NF1 analysis on DNA from a plexiform neurofibroma and from a CAL spot, respectively. Tanito et al proposed that Lisch nodules should be unilateral or ipsilateral to the affected area on the skin to support the diagnosis of MNF1 (10). Contradictory, both patients with Lisch nodules from our MNF1 cohort presented with bilateral Lisch nodules. Currently, a group of European and North American NF1 experts are revising the NF1 diagnostic criteria including the criteria of MNF1 (30).

\section{Conclusion}

Our study on a MNF1 cohort and a review of literature showed that NF1-associated complications such as plexiform neurofibromas and cognitive impairment are present relatively often in patients with MNF1, 
and that debut of complications can occur rather late in life. Our study is supportive of recent literature suggesting that patients with MNF1 should be followed by the same clinical guidelines as patients with generalized NF1 in both childhood and adulthood. Moreover, there should be a greater emphasis among physicians on cognitive challenges in patients with MNF1. An NF1 analysis is advisable both as a diagnostic tool but especially also concerning genetic counseling as patients with MNF1 could have gonadal mosaicism. To develop a specific MNF1 follow-up guideline, there is a need for an international consensus on the diagnostic criteria for MNF1 and a follow-up study conducted in a larger MNF1 cohort.

\section{List Of Abbreviations}

ADHD = Attention deficit hyperactivity disorder

CAL = Café-au-lait

$\mathrm{CRD}=$ Centre for Rare Diseases

MLPA = Multiplex Ligand-dependent Probe Amplification

MNF1 = Mosaic neurofibromatosis type 1

NF1 = Neurofibromatosis type 1

NGS = Next Generation Sequencing

REDCap $=$ Research Electronic Data Capture

MPNST = malignant peripheral nerve sheet tumor

\section{Declarations}

Ethics approval and consent to participate: The study was performed as a quality development project within Centre for Rare Diseases, Department of Paediatrics and Adolescent Medicine. In accordance with the ethics committee in Denmark, no patient consent was needed for this retrospective, descriptive study.

Consent for publication: Not applicable. See above.

Availability of data and materials: Could be available from the corresponding author on reasonable request.

Competing interest: None

Funding: None

Authors' contributions: Conception and design: All authors. Data collection: MR. Data analysis and interpretation: All authors. Manuscript writing: MR, CE. Final approval of manuscript: All authors. 


\section{References}

1. OMIM. MIM No. \#162200, Neurofibromatosis, type 1 ; Online Mendelian Inheritance in Man, OMIM. Johns Hopkins University, Baltimore, MD. 2018.

2. Omim. MIM No. \#613113, Neurofibromin 1; Online Mendelian Inheritance in Man, OMIM. Johns Hopkins University, Baltimore, MD. 2017.

3. Uusitalo E, Leppavirta J, Koffert A, Suominen S, Vahtera J, Vahlberg T, et al. Incidence and mortality of neurofibromatosis: a total population study in Finland. The Journal of investigative dermatology. 2015;135(3):904-6.

4. Evans DG, Howard E, Giblin C, Clancy T, Spencer H, Huson SM, et al. Birth incidence and prevalence of tumor-prone syndromes: estimates from a UK family genetic register service. American journal of medical geneticsPart A. 2010;152A(2):327-32.

5. Ferner RE. Neurofibromatosis 1. European journal of human genetics : EJHG. 2007;15(2):131-8.

6. Gutmann DH, Ferner RE, Listernick RH, Korf BR, Wolters PL, Johnson KJ. Neurofibromatosis type 1. Nature reviewsDisease primers. 2017;3:17004.

7. Messiaen L, Vogt J, Bengesser K, Fu C, Mikhail F, Serra E, et al. Mosaic type-1 NF1 microdeletions as a cause of both generalized and segmental neurofibromatosis type-1 (NF1). Hum Mutat. 2011;32(2):213-9.

8. Ruggieri M, Huson SM. The clinical and diagnostic implications of mosaicism in the neurofibromatoses. Neurology. 2001;56(11):1433-43.

9. Redlick FP, Shaw JC. Segmental neurofibromatosis follows blaschko's lines or dermatomes depending on the cell line affected: case report and literature review. J Cutan Med Surg. 2004;8(5):353-6.

10. Tanito K, Ota A, Kamide R, Nakagawa H, Niimura M. Clinical features of 58 Japanese patients with mosaic neurofibromatosis 1. J Dermatol. 2014;41(8):724-8.

11. Garcia-Romero MT, Parkin P, Lara-Corrales I. Mosaic Neurofibromatosis Type 1: A Systematic Review. Pediatric dermatology. 2016;33(1):9-17.

12. Gutmann DH, Ferner RE, Listernick RH, Korf BR, Wolters PL, Johnson KJ. Neurofibromatosis type 1. Nat Rev Dis Primers. 2017;3:17004.

13. Huson SM. The neurofibromatoses: Classification, Clinical features and Genetic counselling. Kaufmann, editor2008. 7-8 p.

14. Needle MN, Cnaan A, Dattilo J, Chatten J, Phillips PC, Shochat S, et al. Prognostic signs in the surgical management of plexiform neurofibroma: the Children's Hospital of Philadelphia experience, 1974-1994. J Pediatr. 1997;131(5):678-82.

15. Gross AM, Wolters PL, Dombi E, Baldwin A, Whitcomb P, Fisher MJ, et al. Selumetinib in Children with Inoperable Plexiform Neurofibromas. N Engl J Med. 2020;382(15):1430-42. 
16. James AW, Shurell E, Singh A, Dry SM, Eilber FC. Malignant Peripheral Nerve Sheath Tumor. Surg Oncol Clin N Am. 2016;25(4):789-802.

17. Evans DG, Baser ME, McGaughran J, Sharif S, Howard E, Moran A. Malignant peripheral nerve sheath tumours in neurofibromatosis 1. J Med Genet. 2002;39(5):311-4.

18. Stumpf D. Neurofibromatosis. Conference statement. National Institutes of Health Consensus Development Conference. Archives of Neurology. 1988;45(5):575-8.

19. Harris PA, Taylor R, Minor BL, Elliott V, Fernandez M, O'Neal L, et al. The REDCap consortium: Building an international community of software platform partners. J Biomed Inform. 2019;95:103208.

20. Harris PA, Taylor R, Thielke R, Payne J, Gonzalez N, Conde JG. Research electronic data capture (REDCap)-a metadata-driven methodology and workflow process for providing translational research informatics support. J Biomed Inform. 2009;42(2):377-81.

21. Lara-Corrales I, Moazzami M, Garcia-Romero MT, Pope E, Parkin P, Shugar A, et al. Mosaic Neurofibromatosis Type 1 in Children: A Single-Institution Experience. J Cutan Med Surg. 2017;21(5):379-82.

22. Marwaha A, Malach J, Shugar A, Hedges S, Weinstein M, Parkin PC, et al. Genotype-phenotype data from a case series of patients with mosaic neurofibromatosis type 1 . $\mathrm{Br} J$ Dermatol. 2018;179(5):1216-7.

23. Cohen PR. Segmental neurofibromatosis and cancer: report of triple malignancy in a woman with mosaic Neurofibromatosis 1 and review of neoplasms in segmental neurofibromatosis. Dermatol Online J. 2016;22(7).

24. Kim SR, Kibbi N, Imaeda S. Segmental neurofibromatosis 1 with gonosomal mosaicism. Int J Dermatol. 2019;58(12):e255-e6.

25. Friedrich RE, Hagel C, Kohlrusch FK, Schanze I, Wieland I, Zenker M. Mosaic Neurofibromatosis Type 1 With Multiple Cutaneous Diffuse and Plexiform Neurofibromas of the Lower Leg. Anticancer Res. 2020;40(6):3423-7.

26. Listernick R, Mancini AJ, Charrow J. Segmental neurofibromatosis in childhood. Am J Med Genet A. 2003;121a(2):132-5.

27. Kehrer-Sawatzki H, Kluwe L, Sandig C, Kohn M, Wimmer K, Krammer U, et al. High frequency of mosaicism among patients with neurofibromatosis type 1 (NF1) with microdeletions caused by somatic recombination of the JJAZ1 gene. Am J Hum Genet. 2004;75(3):410-23.

28. Petek E, Jenne DE, Smolle J, Binder B, Lasinger W, Windpassinger $C$, et al. Mitotic recombination mediated by the JJAZF1 (KIAA0160) gene causing somatic mosaicism and a new type of constitutional NF1 microdeletion in two children of a mosaic female with only few manifestations. $J$ Med Genet. 2003;40(7):520-5.

29. Ejerskov C, Farholt S, Skovby F, Vestergaard EM, Haagerup A. Clinical presentations of 23 halfsiblings from a mosaic neurofibromatosis type 1 sperm donor. Clinical genetics. 2016;89(3):346-50.

30. Evans G -H, S., Legius, E., - Messiaen, L., - Plotkin, S., - Wolkenstein, Pierre.,. Revision of Neurofibromatosis Diagnostic Criteria USA2018 [Available from: 
https://www.ctf.org/research/review-and-revision-of-the-diagnostic-criteria-of-theneurofibromatoses\#.

\section{Figures}

\section{Articles identified through \\ PubMed search \\ 2013-2020 \\ $\mathrm{n}=26$ articles}

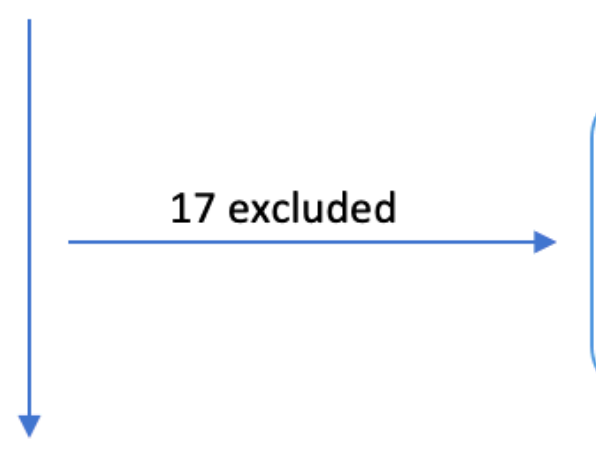

Articles excluded due to:

- Not case report or case series.

- Incomplete clinical information.

- Different diagnosis (generalized NF1, NF2).

Included articles

$\mathrm{n}=9$ articles

six case reports

three case series

Figure 1

Study flow diagram. 